Leyla Hajiyeva ${ }^{1}$

Azerbaijan State University of Economics,

Baku, Azerbaijan
SCIENTIFIC REVIEW ARTICLE doi:10.5937/ekonomika1803037H

Received: March, 26, 2018 Accepted: April, 24, 2018

\title{
THE STUDY OF CONSUMER PREFERENCES OF YOUNG TOURISTS
}

\begin{abstract}
For Azerbaijan which has taken a course on the development of the non-oil sector, tourism is the most preferable and promising sector of the economy. The favorable geographical location between Europe and Asia and the availability of necessary natural conditions contribute to the development of various types of tourism. One of them is youth tourism, the study of features of which is devoted to this article. A study of the needs and preferences of young tourists is aimed at identifying the main factors affecting their decision to travel. Studying the peculiarities of the behavior of young people, tourist enterprises can develop the most appropriate marketing strategy for them.
\end{abstract}

Key words: Strategic maps, non-oil sector, youth tourism, tourism research, tourist activities

JEL classification: M31

\section{ИСТРАЖИВАЮЕ ПОТРОШАЧКИХ ПЕРФЕРЕНЦИЈА МЛАДИХ ТУРИСТА}

\begin{abstract}
Апстракт
За Азербејцан који је усвојио курс о развоју не-нафтног сектора, туризам представља најпожељнији и најперспективнији сектор привреде. Повољна географска локаиија између Европе и Азије и доступност неопходних природних услова доприноси развоју различитих врста туризма. Један од юих је омладински туризам. Студији развоја омладинског туризма је посвећен овај чланк. Студија о потребама и преференцама младих туриста има за иииь да идентификује главне факторе који утичу на њихову одлуку о путовању. Проучавањем специфичних понашањ а младих, туристичка предузећа могу да развију најпогоднију маркетиншку стратегију за њих.
\end{abstract}

Кључне речи: стратешке мапе, не-нафтни сектор, омладински туризам, туристичка истраживања, туристичке активности

\footnotetext{
${ }^{1}$ hajiyeval@mail.ru
} 


\section{Introduction}

Tourism - the most dynamically developing sphere of the economy, that participates in world GDP with 9.8\%. More than 284 million people are engaged in tourism, which means solving social problems of society (Ivana Ilić, Anđelija Nikolić, 2018). In a number of developing countries, tourism is the main source of income providing economic development. So, according to Jankovic Marija, Luburic Veselin, Sofranac Rajko, "tourism is one of the five export categories in $83 \%$ of all countries in the world and a major source of foreign exchange earnings in almost 38\% of countries" (Jankovic Marija, Luburic Veselin, Sofranac Rajko, 2017)

Youth tourism is one of the important sectors of the tourism industry, with its inherent specific features. Thus, according to the research conducted by UNWTO:

- the youth tourism segment is less affected by political unrest and natural disasters;

- this segment is distinguished for its curiosity and attraction to new territories;

- $\quad$ the youth can spend a larger amount on traveling than other tourists can do;

- they also prefer establishing direct contacts with the local population, studying their culture and way of life and at the same time contributing to the development of the places they visit.

The peculiarities of organizing the leisure of the youth include the tolerant nature of travelers in relation to the level of comfort in terms of transportation and accommodation facilities.

In 2016, approximately 2.51 million Azerbaijanis, which is almost a quarter of the country's population, were referred to the category of the youth (from 16 to 30 years old).

Consequently, the trends and preferences of this group are of great importance for the development of the tourism sector. Studying the youth tourist segment will help to identify the specific features and behavior of young tourists, to clarify the main factors affecting their choice of travel, as well as the motives and purpose of the trip.

\section{Tourism in Azerbaijan}

WTO (1995) defines tourism as "the activities of persons traveling to and staying in places outside their usual environment for no more than one consecutive year for leisure, business and other purposes" (Mansour Esmaeil Zaei, Mahin Esmaeil Zaei, 2013). The impact of Travel \& tourism sector on economic growth and job creation can be significant (Bojan Krstić, Vladimir Radivojević, Tanja Stanišić, 2017).

Tourism has prerogative significance for the Azerbaijani economy. Currently, the main course of economic development of the country is to reduce the dependence of the economy on the oil sector and the development of services in Azerbaijan. In this regard, the government of the republic adopted the program of economic development for eleven sectors (Strategic road map on the development of a specialized tourism industry in Azerbaijan Republic, 2016), eight of which are the main sectors, and three are auxiliary.

The priority sector in the country is the tourism sector, whose strategic development map was adopted in December last year. The document provides for state support for the 
development of tourism, turning the country into one of the attractive tourist places, improving the quality and competitiveness of tourism services, attract investment projects and the development of regional tourism in the country.

The strategic development map identifies the main goals of the country's tourism industry until 2020. Achieving these goals is a necessary requirement for the development of tourism in Azerbaijan.

As the first goal, the fullest use of the tourist potential of the capital city of Baku is provided. The capital is the most attractive tourist territory, attracting the attention of foreign tourists. In recent years, the capital hosted a number of economic and culturalsports events of international scale, which, on the one hand, contributed to the growing awareness and information promotion of Baku, on the other hand, to the development of the infrastructure, monumental buildings where were held such events as Eurovision, First European Games, Gymnastics Championships and others. All this led to a radical change in the external appearance of the city, where the number of hotels and hotel-type enterprises has extremely increased.

The second goal of tourism development is the organization of better management at the national level, the creation of tourist and recreational zones, the development of tourism infrastructure at the regional level, simplification of visa procedures and the creation of a favorable climate for the development of tourism in the country.

The next goal set in the Strategic Map for Tourism Development is the development of regional tourism and the creation of an integrated tourism sector that includes all types of tourism, both summer and winter.

The fourth goal envisages the contribution of significant investments in the development of educational projects in the sphere of tourism, the introduction of an improved system of standardization and certification to increase the loyalty of tourists.

According to statistics, over the past 5 years there has been a steady increase in the number of business entities operating in the tourism sector, on average, by $4.5 \%$ per year. The number of foreign tourists visiting Azerbaijan, respectively, increases by $8.5 \%$ per year. Currently, the share of tourism in the country's GDP is about $4.5 \%$, in employment - 8.5\%. In world statistics (World Tourism Barometer, UNWTO, 2016), the share of the sector in question in the world GDP is somewhere around $9.8 \%$. Analysis of statistics allows us to draw conclusions about the importance of the tourism sector in the country's economy.

To analyze the current state of the tourism industry, let us turn to statistical data (Table 1).

Table 1. Breakdown of foreign citizens arriving to Azerbaijan and Azerbaijan citizens travelling abroad by purpose of trip (2)

\begin{tabular}{|l|l|l|l|l|l|l|l|l|}
\hline & $\mathbf{2 0 0 5}$ & $\mathbf{2 0 1 0}$ & $\mathbf{2 0 1 2}$ & $\mathbf{2 0 1 3}$ & $\mathbf{2 0 1 4}$ & $\mathbf{2 0 1 5}$ & $\mathbf{2 0 1 6}$ & $\begin{array}{l}\text { In \% to } \\
\mathbf{2 0 1 5}\end{array}$ \\
\hline $\begin{array}{l}\text { Number of foreign citizens } \\
\text { arriving to Azerbaijan - } \\
\text { total }\end{array}$ & 1282,1 & 1962,9 & 2484,1 & 2508,9 & 2297,8 & 2006,2 & 2248.8 & 112.09 \\
\hline Including tourism purpose & 692,7 & 1279,8 & 1985,9 & 2129,5 & 2159,7 & 1921,9 & 2044.7 & 106.39 \\
\hline $\begin{array}{l}\text { Of which: } \\
\text { eisure, recreation tourism }\end{array}$ & 404,5 & 661,7 & 687,8 & 705,2 & 709,9 & 668,8 & 697.1 & 104.2 \\
\hline
\end{tabular}




\begin{tabular}{|l|l|l|l|l|l|l|l|l|}
\hline business tourism & 261,8 & 547,6 & 595,3 & 648,9 & 670,5 & 632,3 & 691.7 & 109.4 \\
\hline treatment tourism & 7,6 & 14,1 & 43,0 & 46,2 & 46,3 & 36,5 & 41.5 & 113.7 \\
\hline religious tourism & 4,2 & 10,2 & 13,2 & 13,7 & 13,7 & 11,5 & 12.6 & 109.6 \\
\hline other tourism purpose & 14,6 & 46,2 & 38,8 & 41,8 & 42,2 & 30,8 & 39.8 & 129.2 \\
\hline other purpose & 589,4 & 683,1 & 498,2 & 379,4 & 138,1 & 84,3 & 204.1 & 242.1 \\
\hline $\begin{array}{l}\text { Number of Azerbaijan ci- } \\
\text { tizens departured abroad } \\
\text {-total }\end{array}$ & 1829,8 & 3175,6 & 3874,4 & 4284,7 & 4244,3 & 4095,8 & 4281.8 & 104.5 \\
\hline $\begin{array}{l}\text { Including tourism purpose } \\
\text { Of which: }\end{array}$ & 886,9 & 1819,6 & 2828,9 & 3306,7 & 3319,4 & 3256,2 & 3592.1 & 110.3 \\
\hline $\begin{array}{l}\text { leisure, recreation tourism } \\
\text { business tourism }\end{array}$ & 331,7 & 729,3 & 897,6 & 1053,9 & 1014,7 & 1045,2 & 1096.1 & 104.9 \\
\hline treatment tourism & 511,7 & 956,3 & 1172,3 & 1290,9 & 1277,8 & 1185,3 & 1371.6 & 115.7 \\
\hline religious tourism & 23,1 & 43,7 & 116,5 & 169,0 & 169,8 & 140,0 & 192.7 & 137.6 \\
\hline \\
other tourism purpose
\end{tabular}

Source: State Statistical Committee of the Republic of Azerbaijan

\section{Youth tourism and its features}

Currently, there are various definitions of youth tourism.

WYSE Travel Confederation: Youth tourism includes all independent trips (with duration less than a year) of people aged 16 to 29 years who are motivated, in part or in full, by the desire to learn the world, gain life experience and/or benefit from formal or informal training outside the usual habitat (www.wysetc.org).

Birzhakov M.B.: The definition of "youth tourism" includes a special type of travel, individual or collective in form, in the course of which young people prefer to rest with large companies united by the common goal of knowing the world and spending leisure time (Birzhakov M.B., 2005).

Palatkina G.V.: Youth tourism is a way of transferring the life experience and material and cultural heritage gained by the mankind to the younger generations, the formation of value orientations, moral improvement and cultural development of the nation, is one of the ways of socializing the individual (Palatkina Q.V., 2016).

According to Horak and Weber, "youth tourism is defined as all tourism activities that are realized by young whose age are between 15 and 29 years" (Horak \& Weber, 2000).

Glossary of terms of tourism: A specific type of tourist activities for young people and adolescents, implemented both within national borders, and at the regional and global levels. 
Based on the definition of tourism, it can be concluded that youth tourism is a temporary departure of citizens aged 16 to 30 from a permanent residence of no more than six months with the purpose of rest, learning, studying other cultures, and gaining life and professional experience in the country of temporary residence (Hajiyeva L.A., 2017). Youth tourism has a number of socio-cultural advantages, such as increasing youth awareness in the issues of culture, acquiring personal qualities, improving language skills. Thanks to trips, young people become more tolerant towards each other, friendlier, more confident in themselves (Korolyova Y.N., Semenchuk O.V., 2013).

Tourism - one of the most important forms of education of youth, the organization of its free time. The correct organization of tourism can remove many of the youth problems that our society has been facing for several years (Rassohina T.V., Melnik N.V., 2010).

This segment of the tour market, distinguished by age, has a pronounced stereotype of behavior and somewhat differently places tourist priorities. Thus, A. Durovich and A. Kopaev (Durovich A.P., Kopayev A.S., 2012) note that the tendency of changes in tourist mobility is quite clearly traced depending on age, gender and marital status. The greatest propensity to active forms of tourism is demonstrated by the people aged 18-30. Single people are more mobile than married ones.

UNWTO identified the basic motivations of youth tourism as next: "learning, meeting other people, adding value on career development, getting knowledge of other cultures, enhancing self-development, studying, education and traveling which is seen as a part of the youth travellers' identity" (UNWTO, 2011; Demeter \& Brátucu, 2014; King \& Gardiner, 2015).

K. Çakar and F. Seyitoğlu suggest that education is the most important factor influencing the decisions of young travelers (Kadir Çakar, Faruk Seyitoğlu, 2016).

According to Bulqanina S.V., Ananyeva K.V. youth tourism is becoming more relevant at the moment, this is the following reasons (Bulqanina S.V., Ananyeva K.V., 2016):

- the possibility of traveling around the world;

- $\quad$ Economical type of rest;

- $\quad$ acquiring new friends;

- Health promotion and ability to orientate on the terrain;

- $\quad$ preparation for extreme life situations [1];

- availability of discounts when organizing group tours;

- expansion of horizons.

It should be noted that almost no tourist organization has been engaged in the studies of the youth tourism segment in Azerbaijan. Travel agencies pay enough attention to such aspects as advertising, research of their own tourist products, study of competitors, participation in various exhibitions and fairs. But the deep enough research of the youth segment of the tourist market has not yet been conducted. Moreover, most local tourist enterprises are focused on sending tourists abroad. They do not want to specialize in youth tourism, considering it economically unprofitable, if not unprofitable. After all, this category of consumers in our country prefers inexpensive travel using less comfortable means of accommodation and transport. 
Proceeding from this, we put forward the following hypotheses:

1. Youth tourism market in Azerbaijan is underdeveloped.

2. Local travel agencies do not want to organize economical youth tours.

3. The existing range of youth tourism programs is very scarce.

4. The features of this category of consumers have not yet been studied.

5. High tourist activity of young people remains unrealized.

6. This segment of the tour market needs a specific tour product.

7. The price of a tourist product must correspond to the level of consumers' solvency.

In this regard, the policy in the field of tourism in Azerbaijan should be guided by the real needs and opportunities of young people, and should not be only a passive reflection of the current situation.

\section{Methodology}

As a research tool for the study of the youth tourism market, the method of interviewing respondents was chosen, since it allows us to identify the system of preferences that consumers are guided by when choosing certain tourist products.

In our case, a questionnaire was used as a method of research in the collection of primary data. The advantage of the questionnaire is that, as a result of the processing of answers, a quantitative, statistical characteristic of the phenomenon under study can be obtained, causal relationships established.

The questionnaire was conducted during the period from January to March 2017. The place of the study was the Azerbaijan State Economic University. The survey was involved 284 young people. The main source of information were young people aged 16 to 25 years. The respondents were chosen by a random selection procedure.

\section{Research results and data analyses}

The purpose of our study was the study and analysis of consumers of tourism services in the field of youth tourism in Azerbaijan, their capabilities and preferences.

The objectives of our study were:

- $\quad$ identification of the real situation in the youth tourism market of Azerbaijan;

- identification of tourism preferences of young people;

- identification of seasonality of travel;

- $\quad$ designation of the main trends in youth tourism;

- analysis of the activities of travel agencies and airlines focused on young people;

- $\quad$ study of the influence of prices on the activity of youth tours.

As a result of applying simple grouping and classification methods, the following data were obtained: $49.6 \%$ of women and $50.4 \%$ of men participated in the survey. Their age ranged mainly between 16 and 25 years $(92.9 \%)$, respondents aged 26 to 35 were significantly fewer $(4.6 \%)$ and a very small group of 36 to 45 years - just $2.5 \%$.

The analysis of the data obtained showed that $89.6 \%$ of the respondents had to travel at any time ( $47 \%$ of them traveled once a year, $42.6 \%$ - several times a year) and $10.4 \%$ did not have to travel. In this case, in response to the question "Do you 
like to travel?", $97.5 \%$ of respondents answered positively, while only $2.5 \%$ answered negatively.

Of course, all kinds of proposals in the tourism market should be oriented to a specific consumer, his/her wishes, tastes and travel goals. The purposes of travel for different people also vary: someone travels to rest by the water sources, someone wants to go in for sports during the leisure time, someone is interested in excursions and museums, and someone just needs entertainment. The main objectives of travel among respondents were as follows:

- $\quad$ entertainment - 38.5\%,

- $\quad$ travel and rest $-29.6 \%$,

- $\quad$ education $-7.7 \%$,

- $\quad$ shopping - 7,7\%,

- $\quad$ acquaintance with culture - 7\%,

- business $-4.1 \%$.

As follows from the obtained data, the main purpose of tourism for the youth segment is entertainment, recreation and travel; travel agencies should take into account namely these purposes first when organizing tourist packages for young travelers.

Unfortunately, cultural goals that involve acquaintance with other countries and regions, with their customs, traditions and languages, interest in art, as well as business trips, turned out to be less demanded, which is undoubtedly connected with the young age and the sphere of activity of the respondents (most of them are students at the university).

In order to make the need for traveling a mass demand, society must have the necessary level of well-being. The market of tourism products and services, as a rule, effectively works at a sufficiently high standard of living of the population. One of the main restrictions on the market is the purchasing power of citizens and their willingness to spend part of their money on tourism. Naturally, the actual frequency of tourist trips and their duration directly depend on the level and distribution of the income of the respondents. The study revealed a difference in the relationship of young people to domestic and foreign tourism and the means they are willing to spend on local and foreign trips. Thus, $62.5 \%$ of the respondents prefer international tourism, $37.5 \%$ - domestic tourism. In this case, young people are ready to spend the minimum amount of money on domestic trips: $38.5 \%$ from $\$ 100$ to $\$ 200 ; 34 \%$ from $\$ 201$ to $\$ 300,15.3 \%$ from $\$ 301$ to $\$ 400,6.1 \%$ from 401 to 500 dollars and only $5.9 \%$ over 500 dollars.

Quite a different situation is observed with international trips, so in response to the question "What amount are you willing to spend on an international trip?", $23.7 \%$ of the respondents told the amount from $\$ 1,501$ to $\$ 2,000 ; 19 \%$ - from 1001 to 1500 dollars; $16.8 \%$ from 501 to 700 dollars; $15.5 \%$ - from 701 to 1000 dollars, $13.4 \%$ - up to 300 dollars; and $11.6 \%$ - from 301 to 500 dollars.

At the same time, 59 people ( $20.77 \%$ of the respondents) noted that they had never been abroad. Analysis of the data shows that the low price is directly associated with domestic tourism, high - with the international one; most likely, the price factor is the main reason why young people cannot afford international trips.

The geography of the trips was also of interest to the study. The study of the domestic tourist destinations revealed that the popular northeastern regions (Guba, Gebele, Zakatala, Sheki, Nabran) were more popular among young people. Among 
international destinations, the most popular were the neighboring countries - Turkey, Russia, and Georgia. Only 7.7\% of the respondents mentioned European countries, among which Hungary is the leader, which is most likely due to the activities of the Hungarian low-cost Wizzair, which carries out direct budget flights to the Hungarian capital.

Transportation is the important component of the tourism industry and an integral part of tourism products. In our study, the most popular type of transport was auto transport $(58.6 \%)$; this choice is based on taking into account such factors as the level of tariffs, solvency, the length of the route. Taking into account the fact that most of the respondents traveled for relatively short distances, and also was lacking cash, the choice of transport is quite obvious. In the second place in terms of preference was air transport (36.7\%), then buses $27.3 \%$. The least developed in our country is railway transport; unfortunately, long-distance trains do not operate here. This caused the low popularity of the railway transport - only $10.8 \%$ of the respondents chose this vehicle for travel.

Tourism differs due to the influence of seasonality factors, which, in general, are the result of periodic changes in climatic conditions during the year. In our case, the seasonal framework for the market segment under investigation was determined. Thus, the respondents usually travel in winter $-5.7 \%$, in spring $-13.1 \%$, in summer $-67.7 \%$, in fall $-2.5 \%$. At the same time, $23 \%$ of the respondents answered that the time of the year does not affect their desire to travel.

Studies allowed us to reveal that the majority of the young people travel with their families (52.3\%), 38.9\% - with friends and only $14.1 \%$ - alone. These results indicate the need to offer attractive family tour packages for young travelers.

The attitude of young people towards the development of tourism in our country was also of interest to the study. Thus, to the question "How do you assess the development of tourism in Azerbaijan?", 43.5\% answered "normal"; 38.9\% "bad"; 13,1\% - "very bad"; $3.9 \%$ - "good"; $0.7 \%$ - "very good". The indirect attitude towards the services of national tourism sites is also related with this issue: $70 \%$ of the respondents said that they are not satisfied with their services. The main reasons are the lack of qualified personnel, the low level of service, high prices. We must concentrate on the solution of these problems first.

Unfortunately, the main part of the youth tourism in the country is carried out within the framework of amateur tours that do not allow the full development of the tourism infrastructure on the ground and do not bring large revenues to local budgets. Therefore, the primary task for the development of the youth tourism movement in Azerbaijan should be the definition of targeted functions and the development of the promising areas that will help to reveal the potential of specialized tourism products aimed at the youth audience.

The development of low-budget tourism allows reducing the prices for tourist trips regarding the income of the youth audience, since it assumes a reasonable price-quality ratio. In the conditions of the economic crisis, such proposals will be most preferable when choosing tourist trips.

One of the most important problems of youth tourism in our country is the almost complete lack of infrastructure for this type of tourism. Very few youth tourist clubs are left, a system of preferential travel on all types of transportation for young travelers has not been worked out, as in Europe and North America. In a country with a variety of natural landscapes, there are not enough equipped routes for ecological and sports and 
recreational tourism. There is a great deficit of trained specialists for organizing various types of active tourism.

\section{Conclusions}

Summarizing, we should note that it is necessary to develop new routes of both active and cultural-cognitive nature, using innovative technologies of both museum and sports and recreational activities in the sphere of youth tourism.

In general, the main problems for young tourists are:

- expensiveness of tourist services and tours,

- the visa regime,

- $\quad$ the quality of tourism services provided for young people is at a low level;

- $\quad$ small preferences for young people on transport tickets

- practically, there are no modern year-round international student tourist centers in the regions of the country;

- the coordination of the work of the regions with the center is not effective, and there is also practically no interregional interaction and exchange of experience in the field of youth tourism in the regions.

Thus, currently, there are no special tour packages offered for young people; there is a low level of propaganda of youth tourism in the regions of Azerbaijan. Therefore, the development of special programs and effective inter-regional cooperation in the development of domestic tourism are necessary to solve the problems of youth tourism. The most important organizational and technical stages of the development of youth tourism should be, in our opinion, the following:

- $\quad$ training of qualified personnel in the field of youth tourism;

- $\quad$ creation of tourist clubs, youth field camps with public organizations;

- $\quad$ organization of tourist festivals, for example, folklore, cultural festivals with tourist competitions on the most actively developed sports;

- development of youth tourist routes, mainly fully revealing the natural, cultural tourism and recreational potential of the country;

- creation of a national program for the development of youth tourism.

\section{References}

Strategic road map on the development of a specialized tourism industry in Azerbaijan Republic. Baku, 2016

Tourism in Azerbaijan. Statistical yearbook. State Statistical Committee of the Republic of Azerbaijan, 2016

World Tourism Barometer, UNWTO, 2016

World Tourism Organization, Yearbook of Tourism Statistics

Birzhakov M.B Introduction to tourism. M. Nevskiy fond, 2005 
Bojan Krstić, Vladimir Radivojević, Tanja Stanišić. Tourism industry and national Competitiveness: a Sub-saharan Africa Countries perspective. Economica, Year LXIII, I-III 2017, Vol. 1, p.1-19

Bulqanina S.V., Ananyeva K.V., Market research of young people priorities in tourism area. Naukovedenie, V.8, №4, 2016, p.1-17

Demeter, T., \& Brátucu, G. Typologies of Youth Tourism, Bulletin of the Transilvania University of Braşov, Series V: Vol. 7(56), No.1: 115, 2014.

Durovich A.P., Kopayev A.S., Marketing in tourism. M, Econom-press, 2012, 370 p

Ivana Ilić, Anđelija Nikolić, İmplication of modern technology development for the tourism sector of the Republic of Serbia. Ekonomika, 1, 2018, p.41-53

Jankovic Marija, Luburic Veselin, Sofranac Rajko. Sustainable tourism as a basis of management of national parks in Montenegro. Ekonomika, 4, 2017, p.41-53

Kadir Çakar, Faruk Seyitoğlu Youth Tourism: Understanding the Youth Travellers' Motivations, 2016

Korolyova Y.N., Semenchuk O.V. Youth tourism: innovative approach to the development of the regional tourism market. Bulleten of the Samara State Economic University, №3(101), 2013, p.37-41

Mansour Esmaeil Zaei, Mahin Esmaeil Zaei. The impacts of tourism industry on host community, European Journal of Tourism Hospitality and Research Vol.1, No.2, pp.12-21, September 2013

Palatkina Q.V. Youth tourism. Knorus, 2016, 206 p

Hajiyeva L.A. Marketing researches into youth tourism segment in Azerbaijan. International Conference on Social Sciences and humanities. International Balkan University, Book of Abstracts, 12-14 May 2017, Skopye, Makedonia

Horak, S., and Weber, S. (2000). Youth Tourism in Europe: Problems and Prospects, Tourism Recreation Research, 25(3): 37-44

Rassohina T.V., Melnik N.V. Development of youth tourism as the direction of state social innovation policy. Vestnik of New Russian University, №2, 2010, p.177180

Sarah Gardiner, Debra Grace, Ceridwyn King (2015). Is the Australian domestic holiday a thing of the past? Understanding baby boomer, Generation X and Generation Y perceptions and attitude to domestic and international holidays. Journal of Vacation Marketing. Vol 21, Issue 4, 2015

UNWTO (2011). The Power of Youth Travel, AM Reports, Volume 2, Retrieved from, http://www2.unwto.org/publication/am-reports-volume-2-power-youth-travel, Accessed 06.04.2016

www.wysetc.org

https://data.worldbank.org 